\title{
Interconnected Spaces in the Life Narratives of Australian South Sea Islanders
}

\section{Carine Davias}

\section{(2) OpenEdition \\ 1 Journals}

Electronic version

URL: https://journals.openedition.org/ces/4892

DOI: $10.4000 /$ ces.4892

ISSN: 2534-6695

Publisher

SEPC (Société d'études des pays du Commonwealth)

\section{Printed version}

Date of publication: 1 April 2016

Number of pages: 63-71

ISSN: 2270-0633

\section{Electronic reference}

Carine Davias, "Interconnected Spaces in the Life Narratives of Australian South Sea Islanders", Commonwealth Essays and Studies [Online], 38.2 | 2016, Online since 06 April 2021, connection on 01 July 2021. URL: http://journals.openedition.org/ces/4892 ; DOI: https://doi.org/10.4000/ces.4892

\section{(c)}

Commonwealth Essays and Studies is licensed under a Licence Creative Commons Attribution - Pas d'Utilisation Commerciale - Pas de Modification 4.0 International. 


\section{Interconnected Spaces in the Life Narratives of Australian South Sea Islanders}

In commemorating a history of displacement, resettlement and adaptation, the life narratives of Australian South Sea Islanders focus on a long-forgotten past which helps their writers shape a common diasporic identity encompassing people from different South Pacific islands who share a common fund of memories and experiences. These recollections are both rooted in particular places related to their diasporic experience and connected in time and space through remembrance and writing. They thus partake in a rhizomorphic network of transcultural connections extending across national and conceptual boundaries.

In 2013, Australian South Sea Islanders commemorated the $150^{\text {th }}$ anniversary of their ancestors' arrival on the Australian continent in order to work as indentured labour on the cotton and sugar cane plantations of Queensland. These people mainly came from the near-by Melanesian Islands including the Solomons, the New Hebrides (now Vanuatu) and the small Loyalty Islands of New Caledonia, and they represented a cheap labour force who greatly contributed to the economic development of Queensland. The fact that they were abducted, or blackbirded in the first days of the traffic, in addition to the treatment they received once they landed in Australia made them comparable to slaves, despite the abolition of slavery in the British Empire in 1833. Although they were discriminated against, and marginalised by the White Australia policy, these workers managed to settle and adapt to their new social and cultural environment. In 1994, they were officially recognized as a distinct cultural group by the Commonwealth government ${ }^{1}$ and, subsequently, by the Queensland government in 2000.

Since 1977, writers from the Australian South Sea Islander community such as Faith Bandler, Noël Fatnowna, Mabel Edmund, Francis Wimbis and Jacqui Wright have greatly contributed to the formation and recognition of a collective diasporic identity in recalling their personal memories, shared experiences and those of their forebears which all acquire a common dimension through the writing process and become "a privileged carrier of diasporic identity," as shown in the introduction of Diaspora and Memory: Figures of Displacement in Contemporary Literature, Arts and Politics (Baronian et al. 11-2). This identity encompasses a small number of people from different islands ${ }^{2}$ who live in scattered communities situated along the east coast, near the towns formerly associated with the sugar industry. Through their little-known and rarely-studied life narratives, these authors perpetuate their ancestors' memory by putting down in writing their stories of displacement, survival and adaptation orally passed on from one generation to the next. In referring to their ancestors' experience of "blackbirding," the writers also chose to unveil a hidden and contentious part of Australian history as Australian historians like Clive Moore or Peter Corris tended to minimise this practice.

1. The Commonwealth government is the federal government of the Commonwealth of Australia which was created on January 1, 1901 "when six partly self-governing British colonies united to become a nation" (2 February 2016 <http://www.australia.gov.au>). In Australia, the power is shared by the Commonwealth government and the six local governments. The former differs from the Australian government in charge of enacting and upholding the laws voted by the Parliament.

2. About 45,000 people according to Clive Moore in a recent estimate. 
Finally, their life narratives conjure up the importance of the community spaces where they grew up and developed a unifying community consciousness.

The purpose of this essay is therefore to show how writing stimulates processes of memorialisation and identification by weaving together spatial, social, and cultural connections between places and people from different backgrounds. From a theoretical point of view, the context of uprooting and re-rooting in the Pacific region invites the reader to rethink the notions of "home" and "identity" in that space. As the works by Stuart Hall, James Clifford, and Paul Gilroy have earlier demonstrated in different yet analogous circumstances, these notions cannot be considered as fixed entities exclusively tied to one place or one centre insofar as they belong to a network of fluid transcultural and transnational links which resemble the paradigm of the rhizome elected by Deleuze and Guattari, insofar as it allows multiple connections as well as the inclusion of heterogeneity, all of which resist conceptualization in arborescent conceptions of knowledge (Deleuze and Guattari 13). In the introduction to Mille Plateaux, they use the botanical image of the rhizome to describe a process of expansion when a main root has aborted and a new multiplicity of secondary roots come to be grafted onto it and start to develop in an unexpected way (12). In the case of Australian South Sea Islanders, the rhizomatic paradigm helps us better understand successive forms of deterritorialization and reterritorialisation after the loss of their island, their uprooting, dispersion and re-rooting in another place where they try to maintain connections with their island heritage and identity. As a result, this essay first focuses on the places of origin of Australian South Sea Islanders, and the way the former are depicted in narratives transcribing the ancestors' memory. It will then follow the displacement of these populations towards Australian places of settlement, around which small community spaces started to develop, favouring the emergence of a common identification. It will finally become apparent that the narratives of Australian South Sea Islanders rely on the process of memory to map out identity routes between places that become genuine "lieux de mémoire," in keeping with the definition given by French historian Pierre Nora.

The life narratives under discussion were written by authors descended from the first South Sea Islanders who came to work on the sugar cane plantations. Faith Bandler, who wrote Wacvie and Welou My Brother, belongs to the second generation while Noel Fatnowna, the author of Fragments of a Lost Heritage (with the contribution of anthropologist, Roger Keesing), and Francis Wimbis whose story is told by Jacqui Wright in The Secret: A Story of Slavery in Australia, are both members of the third generation. I chose to refer to these narratives as "life narratives" instead of biographies or autobiographies because the term does not enclose them in a predetermined genre that fails to reflect their heterogeneity in form and content. These narratives cast a retrospective glance on the life of the authors and/or their kin, and hinge on two types of memories associated with distinct places: personal remembrances, linked to the authors' lives, and memories borrowed from the accounts of the first islanders relating their abduction and displacement to Australia, as well as their living conditions there. As emphasised by Smith and Watson in Reading Autobiography, by "engaging the past," life narratives enable us to "reflect on identity in the present" (1). This reflection takes into account the representation of places and how they get connected in Australian South Sea Islanders' narratives. 


\section{The Island of Origin as a Place of Anchoring and Uprooting}

Presented in turn as an "island home" (Wimbis and Wright viii), a "homeland" (Fatnowna 82) or "home," the original island is central to the memory of the first islanders, insofar as it represents the place of their childhood, an anchorage in space and time which is linked to their family history, language, customs, beliefs and traditional knowledge - in other words, to their cultural heritage. This inheritance varies from one ancestor to another since they all came from different islands: Fatnowna's grandfather used to live in Malaita, an island from the Solomon group, while Bandler's father, Wacvie, and Wimbis' grandfather came from two islands situated in Vanuatu. Different as they may be, these islands share two characteristics: they all belong to Melanesia, and are all situated in the South Pacific, a vast geographical area where islanders have in common a number of values related to their way of living, such as sharing and helping one another. Orally transmitted by the ancestors from one generation to the next, the island cultural legacy acquires a symbolic value for these writers because of its connection with the often violent and irreversible loss of their place of origin, as indicated in the title of Fatnowna's book, Fragments of a Lost Heritage. It is therefore threatened by oblivion and needs to be remembered.

Because it is depicted as a place of family and cultural anchoring, the island soon becomes synonymous with loss and uprooting when Wacvie is captured and led on an English vessel to work as an indentured labourer in Australia. The same situation is to be found in Fragments and The Secret since the two narratives recount the tragic and traumatic circumstances of the ancestors' kidnapping. Their forced removal induces a loss of identity which finds its concrete expression in the crossing of the sea in the ship's hold, leading the islanders towards the unknown, the world of the white man whose values and lifestyle completely differ from their own. In Wacvie (Bandler 19) and The Secret (Wimbis and Wright 8), this long journey is comparable to a displacement out of time, space and even consciousness during which a violent process of dehumanization is at work. The hold is compared to a dark hole, a cave (Fatnowna 89), or even stinking bowels (Bandler, Wacvie 19). It is the place where South Sea Islanders are locked up, crammed together and mixed like cattle, irrespective of their origin or social status. Those who used to be free are now removed from their islands as prisoners and slaves. In The Secret (4), Jacqui Wright underlines the irony of that "rebirth" through a crude and detailed description of the crimes perpetrated in that place (rapes, murders) that stand in stark contrast with the promise of a wonderful new world made to Wimbis by a missionary who tried to help him escape. The last stage in this transformation consists in changing the islander's original name into an anglicised, simplified version of it, often indicating his geographic origin like Man Tanna or Man Malaita, for instance. Australian South Sea Islanders' stories therefore take shape in a place situated beyond the boundaries of their island where they have no choice but to establish new connections and identifications in a composite environment.

Because of its ambivalence as a place of anchoring and a place of uprooting linked to loss, the island is imbued with symbolic associations in the way the authors portray it from their personal memories, and their captured ancestor's experience. It is recurrently described in Wacvie's nostalgic memories as a place of abundance (6-7) where the lush natural environment provides man with everything he needs, where life itself is ruled by the repetitive cycle of the seasons following one another without interruption. The 
original island leaves an indelible mark on Wacvie's memory where it is often idealised, perpetuated like a frozen picture, surrounded by an everlasting aura: "The blueness of the sky folded into the sea and it was never-ending. It was always like this. Everything was eternal. The moons came and went and came again. The sun came every day" (14). As a place of no return, the island becomes part of the islanders' collective imagination, or even perhaps their unconscious, inspired as it is by legendary stories, dances, customs, beliefs and traditional knowledge that give rise to much fascination. As Fatnowna explains (30), the ancestors impressed the importance of the home island on the minds of their descendants thanks to these stories: "It was like going back to our island itself" (31). Clinging to the memories of their islands also enabled the ancestors to survive during the crossing, and once they arrived in Australia (89).

As a result, recollecting their forebears' memories of the island and those related to their experience of loss and displacement enables the writers to show how common these memories are to all islanders, despite their different islands of origin. The life narratives of Australian South Sea Islanders may therefore be regarded as a means to strengthen a collective identity to which other types of memories also contribute, notably those linked to the places of settlement in their new country.

\section{Places of Settlement in Australia}

Two kinds of places are of particular interest here insofar as they are linked to the lives of South Sea Islanders in their new country: first, the places to which they were brought, and then, the places they chose for themselves, where people create community spaces and share positive and negative memories or experiences. The plantation is the first place where the islanders were forced to settle after being auctioned upon arrival in Australia. Life at the plantation epitomises the power relations between white masters and their black servants, and as such, it is given a detailed description inspired by the ancestor's memories in Wacvie and The Secret. Even if its natural environment and tropical climate remind the islanders of their lost home, the plantation soon turns out to be a hostile place where the feeling of abundance and the working of the earth have been replaced by another form of toil based on productivity, exploitation and discrimination entailing ill-treatment, malnutrition, and physical and mental exhaustion. The supple and rhythmic movements once performed during traditional dances or for navigation have been replaced by repetitive, mechanised gestures to prepare the land for the production of sugar cane (Wimbis and Wright 24). Muscles have hardened; hands have become callous. Echoing the logic of production, the narrative's temporality has also contracted and accelerated, as indicated by the use of shortened sentences built from gerunds in the following example: "Straining, sweating, prising boulders from the earth with crowbars. Hacking at them with picks. Loading them onto sleds" (Wimbis and Wright 19). The plantation seems to work like a reversed image of the island of origin, all the more so as the values, feelings and living conditions associated with each of these two places stand in absolute contrast. Nevertheless, through their close connection with the island's natural environment, their dispersion and their experience of the white man's rule on the plantation, Australian South Sea Islanders come to share a common history and common memories which create connections between them and helps them identify as a group. The fact that they are all called "Kanakas" by the white masters and overseers also contributes to that common identification even though in 
this context "Kanaka" ${ }^{3}$ remains a pejorative term, reflecting a relationship of bondage between white masters and black workers. On top of their hard working and living conditions, the islanders living on the plantation shared a common name and status as well as the Kanaka Pidgin English, the lingua franca thanks to which they could communicate both among themselves and with the white men. Moreover, they gradually converted to Christianity and were allowed to gather for worship once they had completed their work. These circumstances were propitious for the development of a community life and the shaping of a common identity of which Wacvie becomes the spokesman in Bandler's eponymous novel. While raising concern about the conditions of his "fellow islanders" (108) and their spending money on horses or alcohol, he tries to rekindle their community spirit, and tells them: "This place is not good for us. Horses are to work for us, not to take our money. If we come to this place, the money the white man gives us for working, he will now take back - then we can't start to work for our own ground - and our freedom" (109). The recurring use of the personal pronoun "we" can thus be interpreted as a sign of empowerment because it indicates that Wacvie is taking a stand in favour of his community's interests in a long-term strategy of survival designed to help his people to settle in Australia.

Contrary to the plantation, the second category of place of settlement was chosen by the freed ancestor to build a family after his escape, like Wacvie, or because he was allowed to work for himself on a plot of land, like Fatnowna's father. As a gathering place around which the family history is built, it is endowed with a particular emotional value for the writer, and therefore plays an important part in the memories associated with his childhood. Furthermore, this was the place where the ancestors' memory was perpetuated through the stories told at night, in the kitchen, near the fire, as revealed in the following extract from Welou where Bandler's mother, Ivy, discovers the remains of a past that her husband is trying to enliven and share as a foundational part of their history and cultural heritage:

Around the fireplace, as seats for the adults, were pine boxes, some old as the house itself and almost as shiny as the family's Sunday boots. Wacvie always sat on the same box. Each morning, in front of that box, sketched on the ground were illustrations of the stories he had told the night before [...] The boys enjoyed most the stories told of the white winged ships that had gone to the shores of Ambrym in search of men to work the Queensland sugar fields. On the mornings after those stories, Ivy would find islands and ships in the cold grey ashes, and she would shiver, remembering those stories. She felt an affection for this kitchen; it held the past, and the past was the foundation of her family's future. (35-6)

More than their factual content, it is the social significance of these stories from the past that explains why they have made such an important contribution to the forging of a South Sea Islander identity. They exemplify the tension between "living here and remembering/desiring another place" peculiar to diasporic cultures according to Clifford (311), and articulate notions of loss and hope as regards these people's settling in the new country. The latter is given a concrete counterpart through the planting of trees, vegetables and rhizomatic tubers like yams or taros imported by the Islanders as they did not previously grow in Australia. Similarly, in The Secret, Jack Wimbis draws

3. "Kanaka" is actually a Hawaiian word meaning "person" but white people used it as a synonym for "boy" to designate their cheap and docile labour force. 
a comparison between the young mango tree he planted near his new home and his baby son: "You're the first of the new generation born in this land. You'll put your roots into the soil, just like this tree" (52). With the planting of new roots in Australia, the meaning of home undergoes a shift and comes to designate the chosen place of settling, although the memory of the island remains vivid as the place where one belongs. This very verb, however, is increasingly used and repeated in relation to the new settling place, situated as it is in a geographical environment similar to that of the island, near the sea and the mountains, on the fringe of cities. This place also epitomises métissage and diversity in a broadened community space which relies on mutual support and sharing because it gathers black people from different islands, but also Aboriginal people and some whites from different European countries who decided to migrate to Australia for political or economic reasons. Consequently, Australian South Sea Islander identity embraces diversity, as indicated by the name these people chose for themselves. Referring to the experience of Africans the slave trade displaced to the West Indies, Stuart Hall emphasised that same characteristic when he presented his own conception of cultural identities as an ongoing interaction of "points of similarity" and "points of difference" undergoing "constant transformation" due to the "continuous "play' of history, culture and power" ("Cultural Identity and Diaspora" 225). As far as Australian South Sea Islanders are concerned, it is this interplay of shared cultural values and differences inherited from their island customs, their common experience of forced contact with the white man, their subsequent displacement, bondage and adaptation that made a common identification possible in a place where they had to assert their rights as individuals first and then as Australian citizens with an island heritage, in need of recognition for what happened to them and their forebears as well as for their valuable contribution to the economic development of their country. Hence the validity of the rhizome paradigm, and the analogies it contains in terms of growth, dissemination, movement and connection to express the fluid and unpredictable development of Australian South Sea Islander identity as a network of crisscrossing connections between different people, different places and different times across the Pacific Ocean. The life narratives under discussion contribute to that weaving as they link together the memories associated to each of those three components as part of a mapping process: the mapping of Australian South Sea Islander identity.

\section{Writing as a Means to Map Identity}

As already shown, these stories are endowed with a double memorial function, as they weave together the recollections of the ancestor and those of the writer. The narratives partake in a process of memorialisation and ultimately become "lieux de mémoire" because they commemorate the places related to Australian South Sea Islander history of dispersion and resettlement and secure their symbolic meaning for the future generations in recounting the memories they hold. Repeated allusions to the two types of memories aforementioned frequently disrupt the narrative scheme of the story in which they intermingle. These reminiscences produce a temporal discontinuity similar to the discontinuous operations of human memory, as it selects and preserves certain recollections rather than others by virtue of their emotional value, for instance. Supported by the profusion of verbs referring to the remembering process, these memories pervade 
the narrative and commemorate the Elders by paying tribute to their fight for survival. In The Secret, for example, the whole story relies on a mise en abyme enabling the writer to recall the ancestor's story within the narrative frame. Writing is therefore a means to perpetuate these memories, making them available to a wider audience who may have never heard about "blackbirding" or Australian South Sea Islanders, at a local or national level. In their life narratives, the writers articulate collective memory around the places which hold the memories of their forebears' diasporic experience of uprooting, dispersion and re-rooting. As Pierre Nora puts it, these places become "lieux de mémoire" because they bear witness to what happened to Australian South Sea Islanders and acquire a historical dimension. According to him, this passage from memory to history means that each group needs to redefine its identity in revitalising its own history (xxix). This is what Australian South Sea Islander writers are doing here, in trying to fight against oblivion and resist discordant historical accounts which tend to minimise the practice of "blackbirding." As places of memory per se or monuments dedicated to their remembrance, their life narratives partake in the commemoration of their history and identity in connecting fragmented and disseminated memories anchored in the symbolic places associated with their ancestors' history.

Australian South Sea Islander narratives also contribute to a mapping of their identity by weaving together these dispersed places at a local (small community space), national (Australia) and transnational (island of origin) level. These connections form what French sociologist Stéphane Dufoix aptly calls "nonterritorialized links" (106) which literally and metaphorically grow like a rhizome from the seeds planted by South Sea Islander ancestors in Australia and from the words, memories and places shared by the writers.By linking together people and places, the narratives shift in their focus and cause a splintering in identities that are no longer perceived as monolithic, fixed and rooted in a single location but rather as fragmented, moving and related to several places. These diasporic identities shared by both the writers and their characters seem to perpetually extend and reshape themselves when exposed to the dominant culture which caused their splitting through a "process of alterity" and reinterpretation that Bhabha calls "hybridity" (The Location of Culture 251) as Australian South Sea Islanders came to realize that they were no longer quite the same as they were before their encounter with the whites, and that they were perceived as others than themselves through the other's eyes (as "Kanakas" by the white man for instance). Bhabha refers to that process as "a splitting of hybridity that is less than one and double" (166). In addition, the dynamic nature of this reshaping echoes the narratives' textual dynamics due to spatial and temporal discontinuities as well as to the use of oral language, which gives them more spontaneity, especially in Fragments and The Secret. The authors clearly realize that they belong to different places connected to their history and which shape their identity. In the epilogue of Fragments of a Lost Heritage, Noël Fatnowna comments on the town where he lives with his family: "Mackay is almost a part of the Solomons, as it was a hundred years ago" (176). Another example of this feeling of connectedness appears in Wacvie's first chapter, when Faith Bandler describes Ambrym as "a small dot in the vast ocean of the Pacific and one of many islands that make up the New Hebrides" (1). She adds: "Each house has a well-worn path connecting it to the others and the island

4. For further details, see Moore 87. 
is protected by a coral reef" (1). These two quotations reveal that a link exists not only between the people living in a same village, or on a same island but also between all those living in the New Hebrides (now Vanuatu) thanks to the sea. The sea is the link as it has always been in the history of the South Pacific since people from South-East Asia started to colonise these islands. No wonder most Australian South Sea Islanders, including the writers, chose to settle down near the sea, in places related to the sugar industry. To a larger extent, they all seem to share a diasporic consciousness relying on a common, but not an exclusive identity, which echoes the notion of a common regional identity developed by Tongan writer and anthropologist Epili Hau'Ofa as a means to counter any belittling strategies from the Western world which keeps considering the Pacific as a set of small and scattered "islands in a far sea" (31). In an essay entitled "Our Sea of Islands," Hau'Ofa presented instead a new, positive and inspiring vision of Oceania as a huge, interconnected network of islands in the sea where "peoples and cultures moved and mingled, unhindered by boundaries of the kind erected much later by imperial powers" (33). He argued that the awareness of this common space should be propitious for the forging of a shared regional identity, both rooted and mobile, which could help Pacific Islanders defend their collective interests and heritage in order to survive in a ever-changing world. But he also added that this identity was not unique: "The regional identity I am concerned with is something additional to the other identities we already have, or will develop in the future, something that should serve to enrich our other selves" ("The Ocean in Us" 42).

Anchorage and movement, roots and routes: all these features are part of Australian South Sea Islander identity in a South Pacific environment and echo the contemporary definition of the term "diaspora" provided by Stéphane Dufoix according to whom "it can designate both the roots and the rhizome; a persistence in time and space as well as the emergence of new forms of time and space [...] the static nature of identity or its constant transformation; all kinds of identities from the most local to the broadest" (108). Such a definition encompasses "the challenges of modernity and supermodernity" as it goes beyond the traditional opposition between "community diaspora" like the Jewish one for instance and its "hybrid" version associated with "the black diaspora of the Americas" (Bruneau 37).

To conclude, the life narratives written by Australian South Sea Islanders demonstrate their determination to pass their story onto future generations and contribute to the shaping of a common identity as they engage with a history of displacement, relocation and marginalisation through memory. Writing enables them to perpetuate their history and makes it visible on the Australian literary scene, although their books have not yet received the full attention they deserve. Unsurprisingly, many of these accounts are now out of print and remain difficult to find, even in libraries.

By taking a historical, geographical and also a political stand (although I have not had the opportunity to show it here) in favour of a recognition which is still in the making, these life narratives represent precious testimonies on a long-forgotten part of Australian history that is still subject to controversy. They also map out transnational networks of connections between people and places, which characterises the diasporic identity of Australian South Sea Islanders and gives them a stronger sense of belonging to a wider, regional community. As it is difficult today for South Sea Islanders to write 
their story for publication, they resort to new media such as the Internet to create new identity spaces beyond communities and boundaries.

Carine Davias

Paul Valéry University - Montpellier / James Cook University, Australia

\section{Works Cited}

BANDLER, Faith. Wacvie. Adelaide: Rigby, 1977.

-.Welou, My Brother. Glebe, NSW: Wild \& Woolley Pty. Ltd and Aboriginal Artists Agency Ltd, 1984.

Baronian, Marie-Aude, Stephen Besser, and Yolande Jansen, eds. Diaspora and Memory: Figures of Displacement in Contemporary Literature, Arts and Politics. Amsterdam: Rodopi, 2007.

Внавна, Homi. The Location of Culture. 1994. New York: Routledge, 2004.

Bruneau, Michel. "Diasporas, Transnational Spaces and Communities." Diaspora and Transnationalism: Concepts, Theories and Methods. Ed. Rainer Bauböck and Thomas Faist. Amsterdam: Amsterdam UP, 2010.

ClifFord, James. "Diasporas." Cultural Anthropology 9.3 (1994): 302-338.

DAvias, Carine. "Cultural Heritage and Identity." Etropic:TransOceanik Special Edition 12.1 (2013): 33-40.

Deleuze, Gilles, and Félix Guattari. Mille plateaux : Capitalisme et schizophrénie 2. Paris: Minuit, 1980.

Duforx, Stéphane. Diasporas. Trans. William Rodarmor. Berkeley: U of California P, 2008. Trans. of Les Diasporas. Paris: PUF, 2003.

Fatnowna, Noel, and Roger Keesing, eds. Fragments of a Lost Heritage. Sydney: Angus \& Robertson, 1989.

HaLl, Stuart. "Cultural Identities and Diaspora." Framework 36 (1989): 222-37.

Hau'Ofa, Epili. "The Ocean in Us." We are the Ocean: Selected Works. Hawaii: U of Hawaii P, 2008. 41-59.

—. "Our Sea of Islands." We are the Ocean: Selected Works. Hawaii: U of Hawaii P, 2008. 27-40.

Moore, Clive. "Kanakas, Kidnapping and Slavery: Myths from the Nineteenth Century Labour Trade and their Relevance to Australian Melanesians." Kabar Seberang: Sulating Maphilindo 8.9 (1978): 78-92.

NorA, Pierre. "Entre mémoire et histoire. La problématique des lieux." Les lieux de mémoire Vol.1. Ed. Charles-Robert Ageron and Pierre Nora. Paris: Quarto Gallimard, 1984. i-xlii.

SмIтH, Sidonie, and Julia Watson. Reading Autobiography: A Guide for Interpreting Life Narratives. $2^{\text {nd }}$ ed. Minneapolis: U of Minnesota P, 2010.

Wright, Jacqui, in association with Francis Wimbis. The Secret: A Story of Slavery in Australia. Gin Gin, QLD: Wimbis \& Wright, 1996. 